\title{
AL-A'RAF
}

Jurnal Pemikiran Islam dan Filsafat

SURAKARTA

http://ejournal.iainsurakarta.ac.id/index.php/al-araf

ISSN: 1693-9867 (p); 2527-5119 (e)

DOI: $10.22515 /$ ajpif.v14i1.713

\section{FITRAH PERSPEKTIF HADITH: STUDI KRITIK SANAD, MATAN, DAN PEMAHAMANNYA}

\author{
Erwati Aziz \\ IAIN Surakarta
}

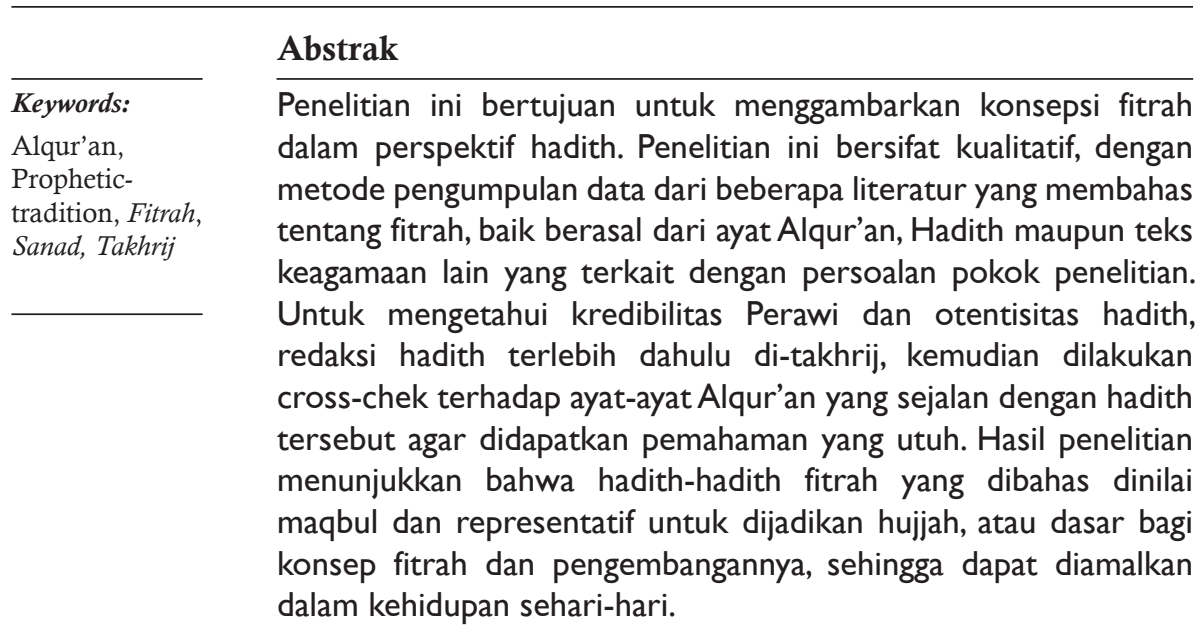

\section{Abstract}

This research aims to describe the conception of fitrah in the perspective of hadith. This is qualitative research, in which the data gathered from the various correlated literature to the focus of the study, such as Alqur'an and Hadith and the other religious texts. Takbrij is necessary conducted in order to know the credibility of rawi and the authenticity of hadith, followed by cross-checking to the qur'anic verses which are in line with the text of hadith in order to find out the comprehensive understanding. Hereby, the result of the research revealed that hadith-hadith which is talking about fitrah discussed, judged as maqbul and representative to be used as hujjah, or fundamental concept of fitrah and it is able to be implemented into the daily life. 


\section{Pendahuluan}

Hadith merupakan sumber ajaran Islam kedua setelah Alqur'an. Hal ini sudah diakui secara ijma' oleh para ulama. Hadith merupakan petunjuk bagi umat Islam dalam menjalani kehidupan di dunia, dan untuk mencapai kebahagiaan di akhirat. Rasulullah SAW. bersabda;

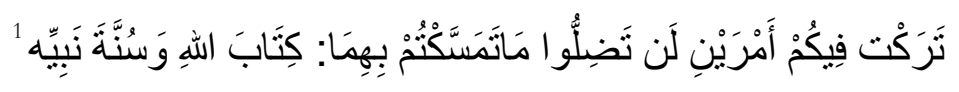

Redaksi hadith di atas menunjukkan bahwa hadith merupakan pedoman hidup bagi umat Islam. Dalam Alqur'an sendiri, terdapat beberapa ayat yang memerintahkan manusia untuk menjadikan hadith sebagai pedoman hidup. Di antaranya, surat Alhashar: 7, yang bisi perintah Allah kepada seluruh umat untuk manusia menggunakan hadith. Kemudian Surat Alnisa': 59 dan hadith yang disampaikan Nabi ketika mengutus Mu'az ke Yaman. Hal ini menunjukkan bahwa Alqur'an dan hadith merupakan dua sumber ajaran Islam yang harus dijadikan pedoman hidup seorang muslim. Keduanya tidak dapat dipisahkan. Hadith merupakan penjelas dari Alqur'an, karena banyak ayat Alqur'an yang masih bersifat global, sehingga memerlukan penjelasan. Di sinilah peran hadith dalam kehidupan manusia.

Berbeda dengan Alqur'an yang ke-bujjah-annya bersifat darury, harus diterima, dan diamalkan tanpa perlu diperiksa kebenarannya, hadith perlu terlebih dahulu diteliti keabsahannya, agar bisa dijadikan bujjah. Pasalnya, ketika satu ayat Alqur'an diturunkan, Nabi langsung menyuruh sahabat untuk menuliskannya. Sementara dalam konteks hadith, ketika disabdakan tidak langsung dituliskan ${ }^{2}$ kecuali ada catatan pribadi sahabat-sahabat

1 Imam Malik, Muwathta', ed. Al-A'zhami (Abu Dabi: Muassasat Zayid bin Sultan, 2004), 1323.

2 Ada dua kelompok hadith yang bertentangan tentang penulisan hadith, ada hadith yang melarang para sahabatnya untuk menuliskan hadith seperti:

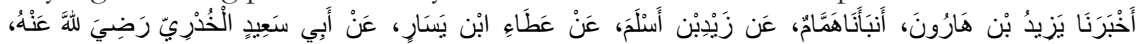

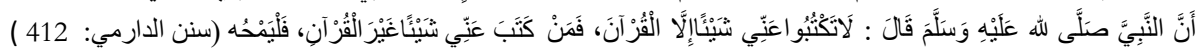
ada tiga hadith yang melarang, dan sebaliknya ada 8 buah hadith yang membolehkan 
tertentu. Selama lebih kurang seratus tahun, hadith beredar dari mulut ke mulut (oral tradition) dengan mengandalkan hafalan. Baru pada awal Abad kedua Hijriyah, atas inisiatif khalifah Umar bin Abdul Aziz, dimulailah pembukuan hadith. ${ }^{3}$ Mengingat begitu lamanya masa pembukuan hadith pasca wafatnya Nabi, keberadaan para pe-rawi sebagai manusia biasa yang tidak lepas dari kekhilafan, maka sangat dibutuhkan ketelitian untuk menjaga orisinalitas sanad dan matan hadith. Mulai dari pertimbangan kredibilitas para pe-rawi hadith, ketidakrancuan matan, keselarasan antara hadith dengan Alqur'an, serta beberap pertimbangan lainnya. ${ }^{4}$

Hadith Nabi SAW memuat berbagai bidang kehidupan umat manusia, khususnya umat Islam, termasuk di antaranya dalam bidang pendidikan. Di sini ada istilah fitrah, yang dipahami sebagai bakat atau pembawaan sejak manusia dilahirkan. Beberapa di antara hadith yang membicarakan konsep fitrah yaitu;

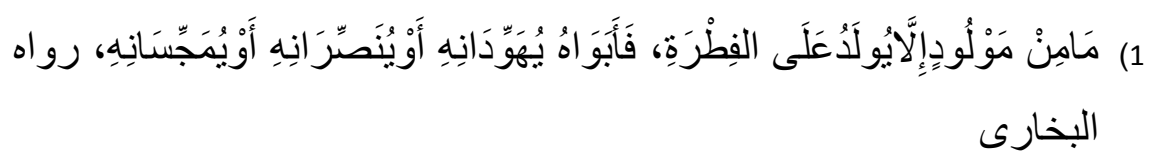

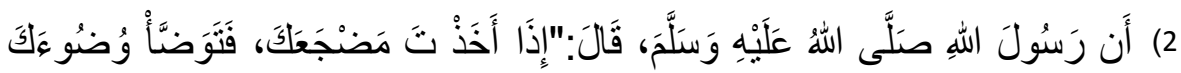

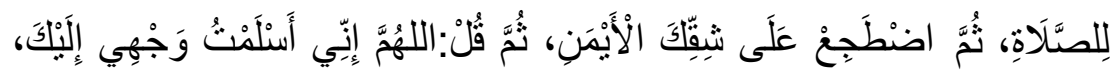

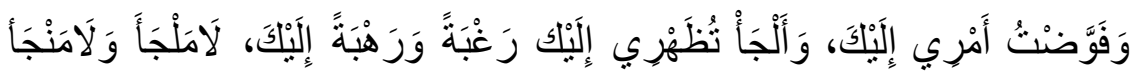

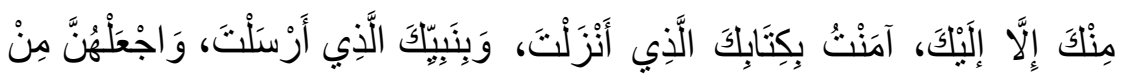

menuliskannya seperti:

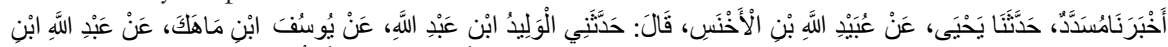

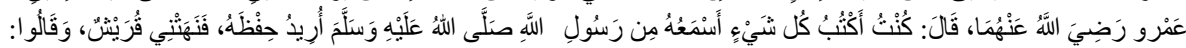

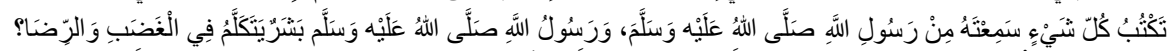

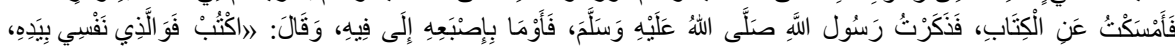

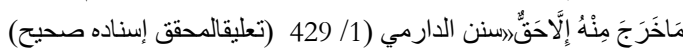

selengkapnya lihat. 'Ajaj Al-Khatib, 'Usul Alhadith (Damaskus: Dar al-Fikr, 1975), $147-$ 151. 147-151.

3 'Ajaj AlKhatib, 'Usul Alhadith. 176.

4 Selanjutnya lihat persyaratan hadith shabib atau maqbul yang diberikan oleh para ulama dalam berbagai kitab hadith seperti 'Ajaj AlKhatib, 'Usul Alhadith., 304-305. 


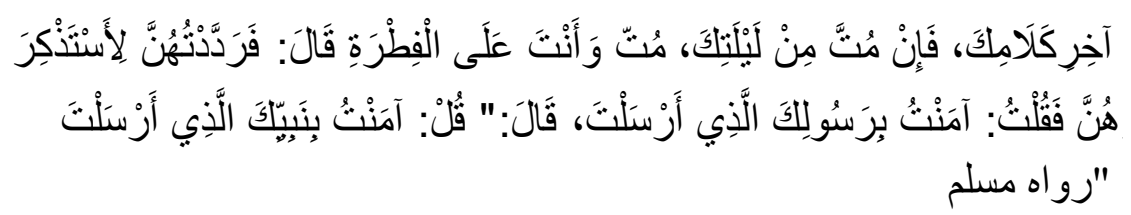

Kedua hadith tersebut diriwayatkan oleh banyak ahli hadith dengan beberapa jalur. Hadith pertama diriwayatkan oleh tidak kurang dari lima (5) ahli hadith dengan 14 jalur sanad. Sementara hadith kedua diriwayatkan tidak kurang oleh lima (5) ahli hadith dengan 12 jalur sanad. Namun dalam studi ini hanya difokuskan pada tujuh (7) jalur; empat (4) jalur hadith pertama, dan tiga (3) jalur hadith kedua. Hadith dari jalur lain dijadikan sebagai shabih dan muttabi' yang membantu tingkat kesahihannya.

Fitrah sebagaimana diungkapkan di atas, merupakan hal yang sangat penting dalam pendidikan. Mengingat, hakekat pendidikan Islam itu sendiri bertujuan untuk mengembangkan fitrah manusia. Istilah ini banyak dipahami oleh masyarakat umum sebagai suci dan bersih, terutama ketika melihat hadith pertama di atas. Apakah benar demikian? Apakah fitrah itu bermakna suci, atau bermakna bakat sebagaimana diungkapkan oleh para ahli pendidikan Islam, seperti Alghazali, Zakiyah Darajat, M. Arifin, ${ }^{5}$ dan sebagainya. Para ahli tersebut lebih fokus pada pembahasan tentang potensi yang dibawa oleh manusia semenjak lahir, dan pengaruhnya terhadap pengembangan pendidikan. Mereka tidak membahas hadith tentang fitrah (secara utuh), hanya menulis tentang fitrah dalam satu sub bahasan. Hadith yang dicantumkan pun sebatas sebagai penguat argumen pendapatnya. Sementara dalam studi ini, dilakukan kritik terhadap sanad dan matan hadith tentang fitrah, kemudian dilengkapi dengan pembahasan yang dilakukan oleh para ahli pendidikan secara umum. Jadi, selain memahami makna dan konteks istilah fitrah dalam hadith di atas, fokus studi ini juga menelusuri tingkat kesahihannya agar dapat dijadikan sebagai dasar hukum. Sehingga hasilnya dapat menunjukkan status ke-bujjah-an hadith dan pemahaman utuh tentang istilah fitrah.

5 Arifin, Ilmu Pendidikan Islam (Jakarta: Bumi Aksara, 2002). 


\section{Standar Kesahihan Hadith}

Untuk mengetahui kesahihan suatu hadith, maka perlu diteliti baik dari sudut sanad maupun dari matan hadith. Standar kesahihan hadith yang digunakan harus sesuai dengan yang telah diberikan oleh para ulama hadith. Para ulama telah merumuskan kaidah kesahihan hadith yang maqbul. Ada lima (5) standar umum kesahihan hadith, seperti diungkapkan Ibnu Shalah, sebagaimana dikutip oleh M.'Ajaj al-Khatib:

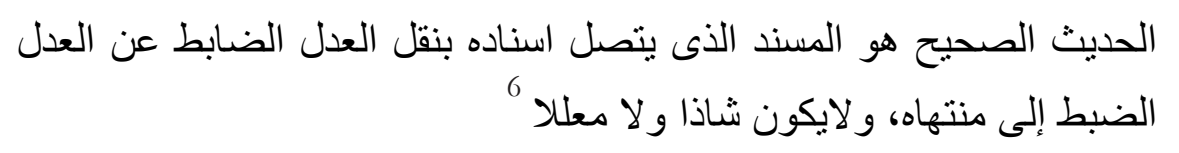

"Hadith sahih yaitu hadith musnad yang bersambung sanadnya, dinukilkan oleh rawi yang adil lagi dabit dari rawi yang adil dan dabit, sampai akhirnya (Nabi saw) tidak syadz dan tidak ber'ila".?

Definisi di atas menjelaskan bahwa suatu hadith dapat dikatakan maqbul atau sabih apabila memenuhi lima (5) syarat, yakni sanad-nya bersambung, rawi-nya adil dan dhabit, tidak ada cacat atau 'illah, dan tidak pula syad\%.

Sanad yang bersambung artinya, mulai dari mukharij-nya seperti Bukhari, Muslim, dan lainnya harus bersambung dengan rawi di atasnya dan seterusnya, hingga sampai kepada Rasulullah SAW sebagai sandaran terakhir. Keadilan rawi meliputi akidah dan akhlaknya baik, tidak fasik, dan selalu menjaga muruah-nya. ${ }^{8}$ Ibnu Sam'aniy merinci lagi keadilan rawi dengan mengatakan empat (4) syarat, yakni: a) selalu memelihara perbuatan taat dan menjauhi maksiat. b) Menjauhi dosa-dosa kecil yang dapat menodai agama dan sopan santun. c) Tidak melakukan perkara mubah yang dapat menggugurkan iman kepada qadar, yang menimbulkan penyesalan. d)

6 AlKhatib, 'Usul Alhadith, 304. Bandingkan dengan Subhi Salih, 'Ulum Alhadith wa Mustalahubu, 17th ed. (Beirut: Dar al- 'Ilm li al-Malayin, 1988), 145.

Subhi Salih, Ulum Alhadith wa Mustalahubu, 305.

8 Subhi Salih, Ulum Albadith Wa Mustalahuhu, 305. 
Tidak mengikuti salah satu mazhab yang bertentangan dengan dasar syara.'

Ke-dhabit-an atau kekuatan ingatan seorang rawi dinilai dengan melakukan perbandingan matan hadith yang disampaikannya dengan matan hadith yang disampaikan oleh rawi lain, yang sudah terkenal ke-dhabitannya. Dapat juga dengan membandingkan matan hadith dengan ayat-ayat Alqur'an yang sudah jelas ke-mutawatir-annya.

dimaksudkan sebagai sebab tersembunyi yang membuat suatu hadith menjadi cacat, sekalipun secara lahiriahnya tampak sempurna atau terlihat shabih. ${ }^{10}$ Menurut, M.'Ajaj al-Khatib العلة yang terdapat pada sanad ini paling banyak, seperti me-mawquf-kan yang marfu'atau sebaliknya. Sekilas terlihat bahwa hadith tersebut mawquf; hanya disandarkan pada sahabat, padahal sebenarnya marfu'. Sebaliknya, hadith yang terlihat lahiriahnya marfu' sampai kepada Nabi SAW, padahal bukan ucapan Nabi SAW tapi ucapan sahabat. Selain itu, me-mursal-kan, memutuskan yang muttasil dan sebagainya. ${ }^{11}$ Untuk menilai العلة, dilakukan dengan cara membandingkan matan dan sanad dari berbagai jalur sanad hadith yang berbeda.

Yang dimaksud tidak Syadz adalah tidak ada kerancuan rawi dalam meriwayatkan hadith. Menurut Shalahuddin bin Ahmad al-Adabi, syadz banyak disebabkan oleh waham atau keraguan. Waham ini sudah dimulai pada rawi pertama yakni sahabat. Contoh waham dalam periwayatan hadith, seperti hadith yang menyatakan, bahwa mayat di-azab karena tangisan dan ratapan keluarganya, bukan karena kesalahan dan dosanya semasa ia hidup. Hadith ini di-marfu'-kan oleh Ibn 'Umar. ${ }^{12}$ Namun oleh 'Aisyah

9 Fathur Rahman, Ikhtisar Musthalahul Hadith (Bandung: Al-Ma'arif, 1970), 97.

10 Salih, Ulum Alhadith wa Mustalabuhu, 179-180.

11 Erwati Aziz, “Imu I'llal Alhadith, n.d.(draft buku Ilmu hadith yang belum diterbitkan)

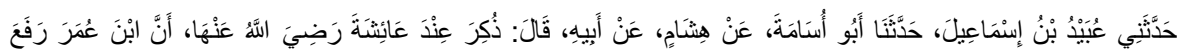

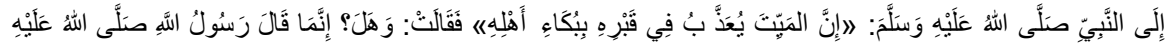

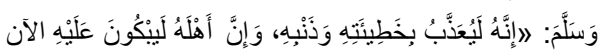

(Telah bercerita kepada kami 'Ubaid bin Ismaill, Telah bercerita kepada kami Abu Usamah, dari Hisyam dari bapaknya dia menyatakan kepada 'Aisyah ra bahwa Ibn 'Umar 
membenarkan hadith ini, dengan menyatakan bahwa mayat tersebut tidak di-azab karena tangisan keluarganya, tapi karena dosa-dosanya.

Sholahuddin menjelaskan sebab-sebab terjadinya waham antara lain; masih sedikitnya hadith yang dibukukan; periwayatan bi al-ma'na atau rawi tidak meriwayatkan hadith sebagaimana diucapkan oleh Nabi SAW, tapi dengan lafaz-nya sendiri. ${ }^{13}$

\section{Metode Historis dan Komparatif}

Penelitian ini adalah penelitian kepustakaan (library research), dengan fokus obyek hadith-hadith Nabi Muhammad SAW tentang fitrah yang sudah terhimpun dalam kitab-kitab hadith. Hadith-hadith tersebut diteliti dari sudut kesahihannya, baik dari sudut sanad maupun matan-nya. Penelitian dilakukan dengan meneliti kitab-kitab yang memuat dan menjelaskan para rawi, mulai dari sahabat dan seterusnya, sampai pada mukharij-nya. Sedangkan untuk matan hadith, dilakukan dengan cara membandingkan dengan hadith-hadith yang sama, dari jalur yang berbeda.

Pengumpulan data dimulai dari mengumpulkan hadith-hadith tentang fitrah dalam kitab-kitab hadith, atau disebut dengan takhrij hadith. Kegiatan ini dilakukan dengan bantuan kamus hadith al-Mu'jam alMufabras li Alfazh al-Ahadith al-Nabawi. Mulai dari penelusuran kata الفطرة, dilanjutkan dengan penelusuran dalam kitab-kitab hadith yang ditunjuk, lalu dilakukan inventarisasi para rawi dan menganalisanya untuk melihat ketersambungan sanad dan kredibilitas para rawi.

Penelitian sanad dan matan menggunakan dua metode, yaitu sejarah dan perbandingan. Metode sejarah digunakan untuk melihat dan mengkritisi biografi para rawi dengan tujuan mengetahui ketersambungan

memarfu'kan hadis kepada Nabi saw: Sesungguhnya mayat diazab di kuburnya dengan tangisan keluarganya. 'Aisyah berkata Apa? Sesuangguhnya Rasulullah saw bersabda Sesungguhnya dia (mayit) sungguh diazab karena kesalahan dan dosanya, sesungguhnya keluarganya menangisinya sekarang).

13 Shalah al-Din ibn Ahmad Al-Adabi, Manhaj Naqd Al-Mutun (Beirut: Dar alAfaz al-Jadidah, 1983), 80-82. 
sanad-nya dengan melihat tahun kelahiran dan wafatnya. Selain itu dilihat pula sejarah periwayatannya, sighat yang digunakan oleh seorang rawi dalam menerima dan menyampaikan suatu hadith (sighat tahammul wa al$\left.a d a^{\prime}\right)$. Sejarah juga digunakan untuk menilai kredibilitas rawi, mulai dari perilaku dalam kesehariannya, keberagamaan, dan sebagainya. Sementara penerapan metode sejarah pada matan adalah dengan mengetahui latar belakang munculnya hadith, sejarah yang melingkupinya, serta kapan hadith itu kembali disampaikan oleh sahabat yang menerimanya dari Nabi SAW kepada rawi berikutnya.

Metode perbandingan dilakukan dengan berbagai cara, antara lain membandingkan antara hadith yang disampaikan beberapa murid yang diterimanya dari seorang ulama hadith. ${ }^{14}$ Kemudian membandingkan pernyataan seorang ulama hadith pada waktu yang berbeda. Hal ini pernah dilakukan oleh 'Aisyah terhadap suatu hadith yang diriwayatkan oleh Ibnu 'Umar. ${ }^{15}$ Selain itu juga membandingkan dokumen hadith yang tertulis dengan ucapan lisan. Hal ini dilakukan, ketika seseorang mendengar seorang rawi mengucapkan suatu hadith, yang menerimanya tidak puas begitu saja tapi mengecek ulang pada catatan hadith yang dimilikinya atau milik orang lain. ${ }^{16}$ Kalau ditemukan perbedaan antara matan hadith yang berasal dari ucapan lisan dengan yang sudah tertulis dalam kitab hadith, maka yang dipegangi adalah yang tertulis dalam kitab hadith. Yang tidak kalah penting adalah membandingkan matan hadith dengan ayat Alqur'an. Metode ini dilakukan oleh 'Umar dalam menolak hadis Ibn Qais tentang uang perawatan bagi wanita cerai yang bertentangan dengan Alqur'an surat

${ }^{14}$ M.M Azami, Studies in Hadith Metodology and Literature, ed. Meth Kieraha (Jakarta: Lentera, 1995). 76-77.

15 'Aisyah menyuruh 'Urwah menanyakan suatu hadis kepada Ibnu 'Umar, kemudian setelah setahun berselang kembali 'Aisyah menyuruh 'Urwah menanyakan kembali hadith tersebut. Ternyata Ibnu 'Umar menyampaikan hadith yang sama persis. M.M Azami, Studies in Hadith Metodology and Literature, 80.

16 M.M Azami, Studies in Hadith Metodology and Literature, 81. 
Thalaq ayat $1 .{ }^{17}$ Hal yang sama juga dikemukakan oleh Muzfar 'Azmillah al-Damini dalam memberikan tolok ukur kesahihan matan. ${ }^{18}$ Selanjutnya dibandingkan lafaz, hadith dari beberapa jalur, sehingga diketahui apakah telah terjadi periwayatan bi al-ma'na, apakah perbedaan lafaz tersebut membawa kepada ke-dha'if-an hadith atau tidak.

Selain kedua metode di atas, digunakan pula penggunaan rasio, tetapi dengan catatan tidak boleh berlebihan. Artinya, jika ada hadith yang tidak sesuai dengan akal (bukan berarti) langsung ditolak, tapi perlu dilihat juga kesaksian para rawi. Penggunaan rasio pada sanad, misalnya dengan menilai pernyataan seorang rawi bahwa ia menerima hadith dari seorang guru pada tahun 90 Hijriah, padahal sang guru telah meninggal sebelun tahun tersebut. Jadi rawi tersebut diketahui kebohongannya. Artinya, dia bukan menerima hadith tersebut dari guru yang dimaksud tapi dari orang lain yang mungkin menerima dari guru tersebut.

Setelah dilakukan penelitian sanad dan matan, serta status ke-bujjahahan hadith, langkah selanjutnya adalah analisa pemahaman makna fitrah dalam hadith. Hal ini dilakukan dengan cara mencari kosa kata fitrah secara bahasa, lalu membandingkannya dengan hadith-hadith lain dan ayat-ayat Alqur'an.

\section{Mencermati Lafaz dan Matan Hadith}

\section{Lafaz Hadith}

Berikut ini beberapa lafaz hadith yang menjadi obyek penelitian ini: Hadith dari Imam Malik:

\footnotetext{
17 M.M Azami, Studies in Hadith Metodology and Literature, 82.

18 Uraian selengkapnya lihat, Musfar 'Azmillah Al-Damini, Maqayis Naqd Mutun Alsunnah (Riyadh, 1984), 57-261. ; Lihat juga AlAdabi, Manhaj Naqd Almutun, 103.
} 


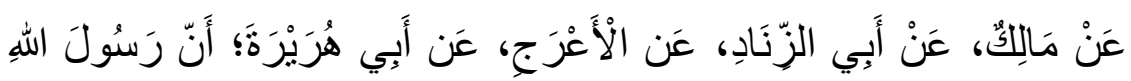

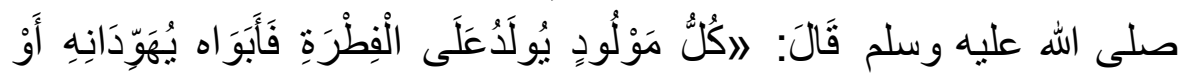

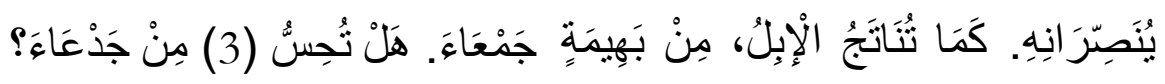

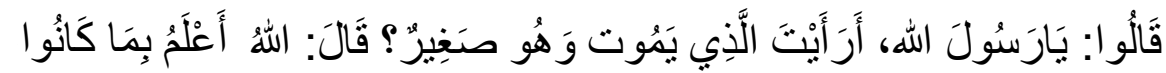
19 عَا مِلِينَ. (رو اه مالكَ) بارسول

Hadith dari Imam Muslim:

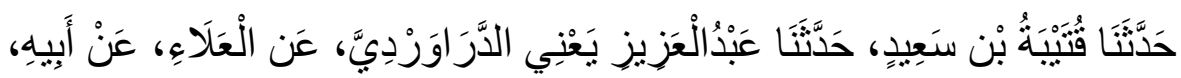

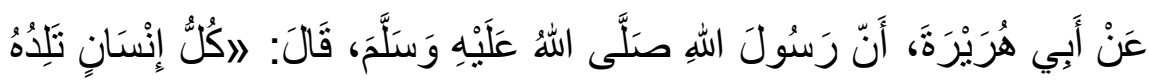

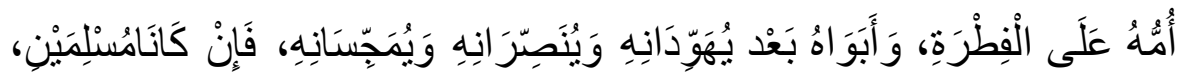

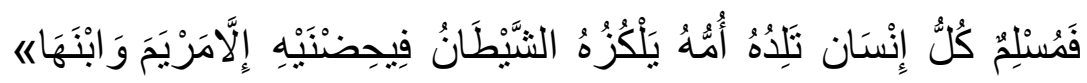
20 (رو اه مسلم)

Hadith dari Turmudzi:

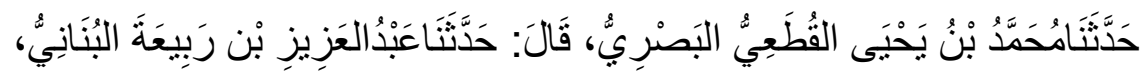

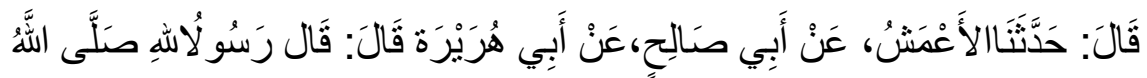

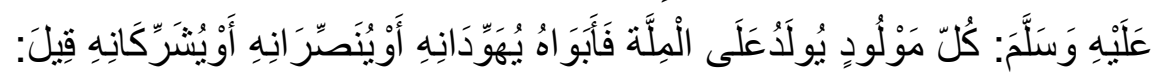

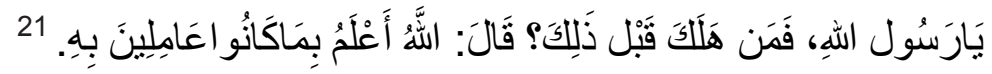

19 Malik bin Anas, Muwathta', ed. Al-A'zhami (Abu Dhabi: Muassasah Zaid bin Sulthan, 2004), 338.

20 Abu al-Husain Muslim bin al-Hajjaj Al-Naisaburi, Shabih Muslim (Beirut: Dar al-Kutub al-'Tlmiyah, n.d.), 459.

21 Abu 'Isa Muhammad bin 'Isa bin Saurah bin Musa bin ad-Dahhak As-Sulami at- Turmudzi, SunanTurmudzi, ed. Ahmad Muhammad Syakir (Mesir: Musthafa al-Bab al-Halabi, 1975), 15. 
Hadith Abu Dawud:

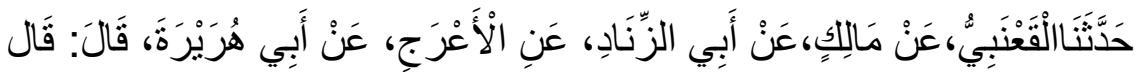

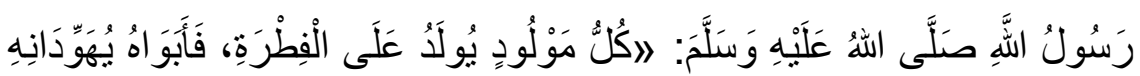

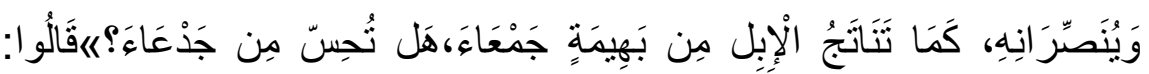

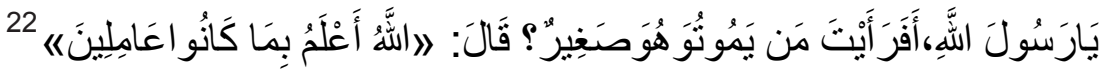
Hadith dari Turmudzi:

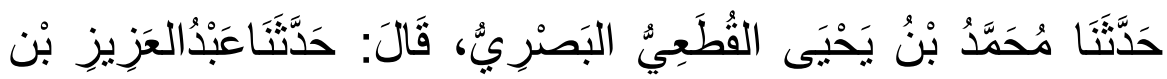

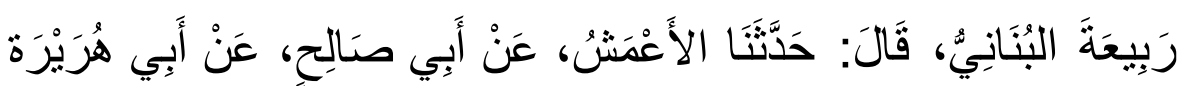

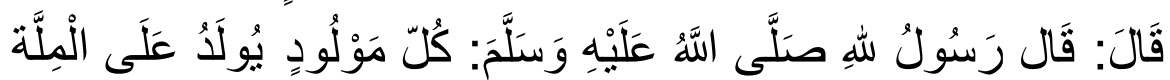

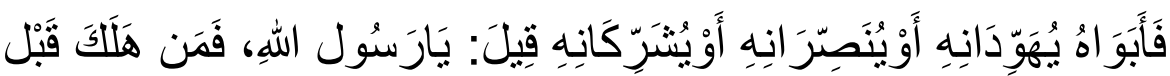

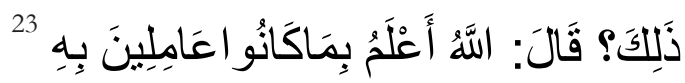

Hadith Abu Dawud:

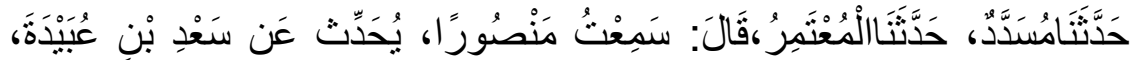

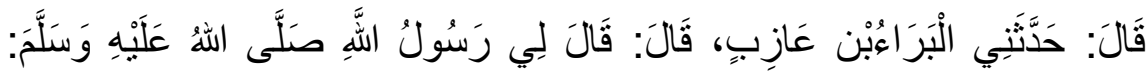

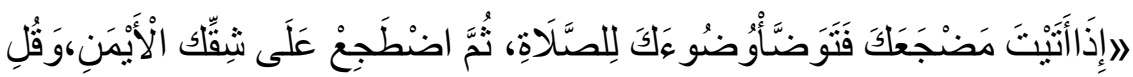

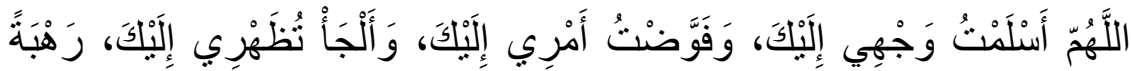

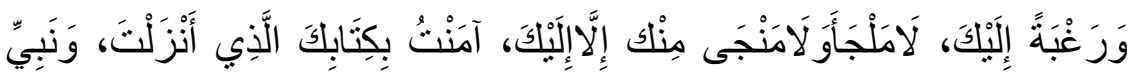

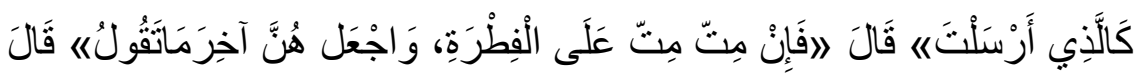

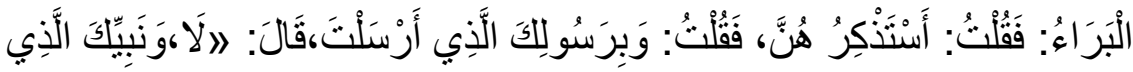

$$
24 \text { أَرْنَلْتَنَ }
$$

22 Abu Dawud Sulaiman bin Al-Asy'ats As-Sijistani, Sunan Abu Dawnd (Indonesia: Maktabah Dahlan, n.d.), 229.

23 Turmudzi, SunanTurmudzi. 469; Turmudzi memberikan penilaian hasan gharib terhadap hadith melalui jalur Rafi' bin Khadij.

24 As-Sijistani, Sunan Abu Dawud, 311. 
Hadith dari Darimi:

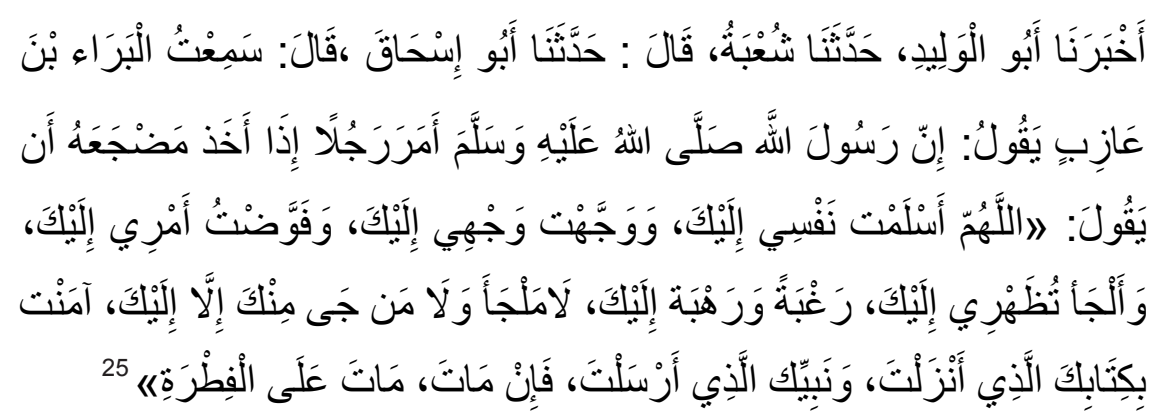

Setelah menelusuri biografi para rawi hadith yang diriwayatkan oleh Imam Malik, Abu Dawud, ${ }^{26}$ rawi hadith riwayat Muslim, ${ }^{27}$ rawi jalur alTurmudzi, ${ }^{28}$ maka dapat ditarik kesimpulan bahwa sanad-nya muttasil. Hal ini dapat dilihat dari tahun kelahiran dan wafatnya para rawi. Sekalipun tanggal lahirnya tidak diketahui, tapi dilihat dari thabaqah-nya mereka bertemu. Begitu juga dari adanya hubungan guru dan murid. Mereka semua merupakan guru dan murid. Dari sighat tahammul, para rawi menggunakan sighat yang berbeda, namun masuk kategori hadith maqbul. Sekalipun sighat tabammul wa Alada' yang digunakan adalah ' $A n$ dan $A n$, namun semua rawi-nya dinilai thiqqah, dhabat, hafiøh, jadi sesuai dengan persyaratan ulama

25 Abu Muhammad 'Abdullah bin 'Abd al-Rahman Al-Darimi, Sunan Al-Darimi (Beirut: Dar al-Kutub al-'Ilmiyat, 1971), 1756.

26 Lihat Salih, 'Ulum Albadith wa Mustalabubu, 360.; Ibn 'Asakir Abu al-Qasim 'Ali bin Hasan, Tarikh Dimasyq (dar al-Fikr li al-Thaba'ah wa al-Nasyr, 1995), 23.; Syams al-Din Muhammad bin Ahmad Al-Dzahabi, Mizan Ali'tidal fi Naqd Alrijal (Beirut: Dar al-Kutub al-'Ilmiyat, 1971), 94.; lihat juga Ibnu Hajar Al-Asqalan, Tahdhib Altahdhib (Hadrabat: Majlis al-Dairat al-Nizamiyah, n.d.), 182.; Azami, Studies in Hadith Metodology and Literature, 118.; Abu al-'Abbas Syams al-Din Ahmad bin Muhammad bin Ibrahim bin Abu Bakr ibn Khalkan Al-Barmaki, Qiyat Ala'yan, ed. Ihsan 'Abbas (Beirut: Dar Sadir, 1900), 40.; Rahman, Ikhtisar Musthalahul Hadith, 331.

27 Al-Asqalan, Tahdhib Altabdhib. jilid VI, 266, jilid VIII, 160; jilid VI, 310; jilid VI, 310; jilid VIII, 311; jilid 10, 127. Lihat juga, Salih, 'Ulum Alhadith wa Mustalabubu, 398.

28 Al-Asqalan, Tahdhib Altabdhib. , jilid III, 195-196, , jilid VI, 295-296, jilid IX, 438-439, jilid IX, 438-439; Al-Dzahabi Abu 'Abd Allah Muhammad bin Ahmad bin 'Utsman, Mizan Al-I'tidal Fi Naqd Al-Rijal (Beirut: Dar al-Kutub al-'Ilmiyah, 1995). jilid II, 224. Salih, 'Ulum Al-Hadith Wa Mustalabubu, 399. 
hadith tentang hadith mu'an'an dan muanan yang dinilai muttasil. Sementara dari kredibilitas rawi tampak, bahwa semua rawi-nya dinilai dengan penilaian hadith yang maqbul seperti thiqqah, dhabat, hafizh dan sebagainya. Sehingga dapat disimpulkan bahwa keempat hadith tersebut, dari sudut sanad termasuk hadith maqbul.

Adapun hadith kedua, sesuai dari kitab Rijal al-badith ${ }^{29}$ terlihat bahwa sanad hadith riwayat Abu Dawud, al-Darimi, ${ }^{30}$ dan al-Turmudzi ${ }^{31}$ bersambung. Hal ini dapat dilihat dari tahun kelahiran atau usia, kesemuanya merupakan guru dan murid. Adapun sighat tahammul yang digunakan beragam. Semuanya merupakan sighat yang tertinggi, kecuali satu: antara Mansur dan Sa'ad bin 'Ubaidah menggunakan sighat ع, namun karena keduanya dinilai sebagai rawi yang thiqqah maka dapat dikatakan sanad-nya bersambung. Dari sudut kredibilitas rawi-nya, para ulama memberikan penilaian yang beragam, namun semuanya berada pada tingkat yang maqbul, seperti thiqqah, hafiz, dhabat, dan lain sebagainya, kecuali satu, yakni Abu Ishak. Abu Ishak dinilai thiqqah pada awalnya, tapi mukhtalit pada akhir hayatnya. sehingga dapat disimpulkan bahwa ketujuh hadith tersebut sanad-nya muttasil (bersambung). Hal ini dapat dilihat dari tahun kelahiran dan wafatnya para rawi. Begitu juga kalau dilihat dari sighat Tahammul wa Alada' yang digunakan adalah ' $A n$ dan $A n$, namun semua rawi-nya dinilai thiqqah, dhabat, hafir, karena itu dinilai muttasil. Adapun dari kredibilitas rawi tampak bahwa semuanya dinilai maqbul, seperti thiqqah, dhabat, hafir. dan sebagainya, kecuali satu Abu Ishak yang dinilai thiqah pada awalnya, namun diakhir hidupnya dia dinilai mukhtalithth namun bukan pada hadith

29 Al-Asqalan, Tahdhib Al-Tahdhib., jilid I, 388; jilid Iii, 417; jilid X, 279-280; jilid X, 205, jilid 10, 98-99.

${ }^{30}$ Yusuf bin "Abd al-Rahman bin Yusuf Abu al-Hajjjaj Jamaluddin ibn al-Zakiy Abi Muhammad al-Qadha"i al-Kalbiy Al-Mizzi, Tahdbib Alkamal fi Asma' Alrijal (Beirut: Muassasat al-Risalah, 1992)., Al-Asqalan, Tahdhib Altabdhib., jilid IV, 308-314, jilid II, 4244, jilid V, 361-362.

31 Al-Asqalan, Tahdhib Altahdhib., jilid III, 205, jilid XI, 157, jilid XI, 234, jilid 7, 276, jilid 9, 72. 
ini. Karena itu dari sudut sanad ketujuh jalur hadith tersebut bernilai sabih atau maqbul.

\section{Periwayatan bi al-Ma'na}

Keempat hadith pertama di atas, berbicara pada hal yang sama: yakni bahwa semua manusia dilahirkan atas fitrah. Meski lafaz-nya yang sedikit berbeda, tapi maknanya tetap sama. Hadith Imam Malik menggunakan lafar, كُل مَوْلُودٍ (setiap anak), tidak menggunakan lafar memulainya dengan menyatakan bahwa setiap manusia dilahirkan ibunya)

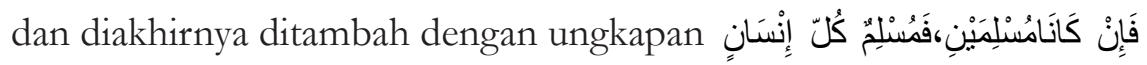

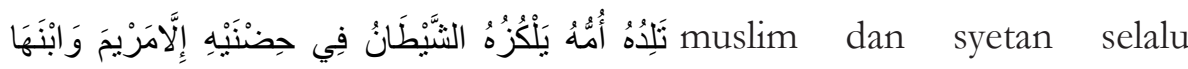
menggganggunya kecuali maryam dan putranya). Imam Turmudzi

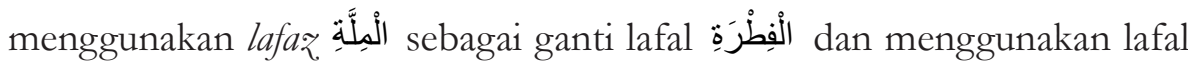

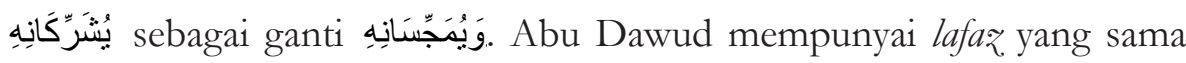
dengan lafal Imam Malik, karena ia melalui jalur Imam Malik. Hal inilah antara lain yang menyebabkan peneliti memilih keempat lafaz, tersebut, karena mempunyai lafaz yang berbeda dengan jalur Bukhari dan Imam Muslim serta lainya. Dengan demikian, keempat hadis ini diriwayatkan melalui periwayatan bi al-ma'na.

Walaupun terdapat perbedaan lafaz, apabila diperhatikan mendalam semuanya dapat dikatakan mengandung makna yang sama, meski penekanannya sedikit berbeda. Lafaz yang menggunakan nafi dan ithbat lebih tegas daripada lafaz, khabar biasa. Sementara lafaz, الْمَنَّة merupakan

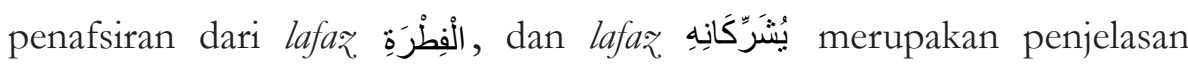
dari وَيُمَجِّنَانِهِ karena memang kaum Majusi itu adalah musyrik. Dengan demikian, periwayatan bi al-ma'na masih pada taraf yang bisa diterima karena tidak mengganggu ma'na, dan tidak pula termasuk pad illal karena pertukaran tersebut hanya merupakan penjelasan, bukan lafaz yang tidak dapat dipertemukan. Sehingga dapat disimpulkan bahwa sekalipun ada 
periwayatan bi al-ma'na, namun tidak sampai membuat hadithnya mardud atau ditolak, karena perbedaan tersebut masih dalam level yang bisa ditoleransi.

Tidak berbeda dengan hadith yang pertama, ketiga hadith kelompok kedua juga mengalami periwayatan bi al-ma'na. Hadith Turmudzi pada sabda

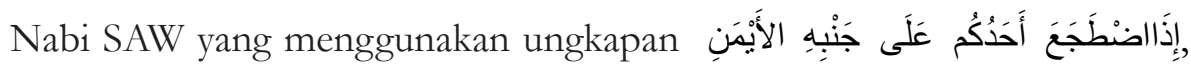

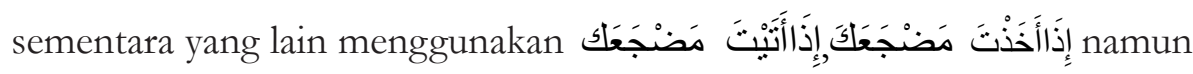
kesemuanya itu bermakna apabila mau tidur. Dengan kata lain, hanya perbedaan lafaz saja. Ada perbedaan lain, yakni ungkapan وَبَرَسُوِلِكَ dengan

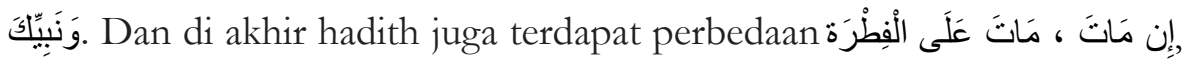
namun jika diamati, perbedaan lafaz, tersebut tidak membawa kerusakan makna, sehingga tidak sampai membuat hadithnya mardud atau dha'if.

\section{Matan Hadith}

Matan kedua hadith tersebut tidak bertentangan dengan ayat Alqur'an. Bahkan maknanya sejalan dengan Q.S. al-A'raf ayat 172. Dalam ayat tersebut dijelaskan bahwa semua manusia telah mengakui keesaan Allah sejak azali. Mereka semua telah mengambil janji Allah yang telah menciptakan semua manusia dengan membawa potensi tauhid atau fitrah tauhid. Hal itu juga dipertegas dalam Q.S. al-Rum ayat 30.

Q.S. al-Rum ayat 30 menjelaskan bahwa Allah telah menciptakan semua manusia dalam keadaan fitrah, dan itu yang tidak akan berubah selama-lamanya. Fitrah yang dimaksud adalah tampak pada lanjutan ayat

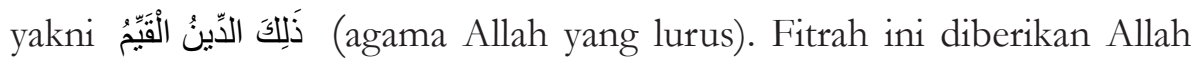
sejak manusia masih berupa ruh dalam sulbi Adam (Q.S. al-A'raf). Dalam Q.S. al-Rum dijelaskan Allah bahwa fitrah tersebut tidak akan berubah. Sebagai buktinya, dapat dilihat dalam penjelasan Allah melalui Q.S. Yunus ayat 90. Dalam ayat lain, Allah memberikan kisah Fir'aun yang sangat durhaka bahkan mengaku dirinya sebagai Tuhan. Ketika sudah terdesak, 
fitrahnya muncul ke permukaan sehingga dia menyatakan bahwa dia beriman dengan Allah, tapi sudah terlambat.

Dengan demikian, tampak bahwa kedua hadith ini tidak bertentangan dengan Alqur'an. Bahkan dalam menafsirkan Q.S. al-Rum ayat 30 dan Q.S. al-A'raf ayat 172, para mufasir seperti al-Maraghi misalnya, menafsirkan Q.S. al-A'raf ayat 172 dengan mengatakan bahwa fitrah yang dimaksud

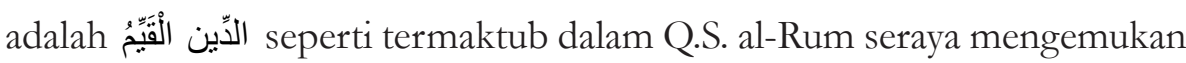
hadith ini. ${ }^{32}$ Ketika menafsirkan Q.S. al-Rum dia mengatakan bahwa Allah telah menciptakan manusia dengan fitrahnya yang cenderung kepada tauhid. $^{33}$

Hal yang sama juga dilakukan Quraish Shihab, dengan menyatakan bahwa Q.S. al-Rum ayat 30 ini diperkuat oleh hadith ini. ${ }^{34}$ Begitu pula dalam tafsir Q.S. al-A'raf ayat 172, ia mengatakan setelah Allah mengambil kesaksian dan pengakuan tentang keesaaan Allah dan mereka semua mengakuinya, pada hakikatnya mereka memiliki pengetahuan serta fitrah yang mengandung pengakuan ini. Hal ini sejalan dengan sabda Rasul SAW, dan ia mencantumkan hadith ini. ${ }^{35}$

Begitu pula dengan hadith lain yang mendukung hadith tersebut sebagaimana yang diriwayatkan Imam Muslim berikut:

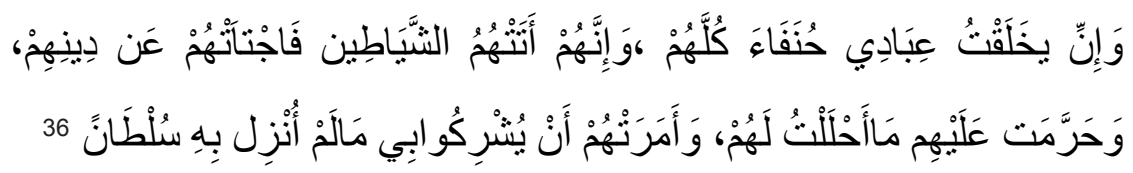

Hadith ini mendukung hadith yang dibahas, bahwa Allah telah menciptakan manusia yang cenderung kepada agama yang hanif, yakni agama tauhid tapi setanlah yang memalingkan mereka darinya.

32 Ahmad Mustafa Al-Maraghi, Tafsir Almaraghi (Beirut: Dar al-Fikr, 1974), 103104.

33 Al-Maraghi, Tafsir Almaraghi., jilid VII, 45-46.

34 M.Quraish Shihab, Tafsir Alishbah, Pesan, Kesan dan Keserasian Alqur'an (Jakarta: Lentera Hati, 2002). jilid 10, 208.

35 M.Quraish Shihab, Tafsir Al-Mishbah,.. jilid 4, 370.

36 Al-Naisaburi, Shabih Muslim. jilid IV, 2197. 


\section{Fitrah: Tauhid Sejak Jaman Azali}

Secara etimologis, fitrah berasal dari bahasa Arab: فطر يفر فطرة yang berarti penciptaan. Menurut al-Raghib al-Asfihani, makna asal dari الفِطَرَة adalah belahan memanjang. Sedangkan kaitannya dengan penciptaan manusia atas fitrah, dimaksudkan sebagai potensi untuk mengenal Allah dan untuk beriman kepada-Nya. ${ }^{37}$

Lafaz, hadith menggunakan عَلَى bukan dengan فى , artinya Allah menciptakan manusia atas dasar fitrah, bukan dalam fitrah. Jika dilihat kembali pada hadith ke dua di atas, yang menjelaskan tentang do'a sebelum tidur, ketika Nabi SAW memerintahkan untuk berwudhu dan membaca do'a sebelum tidur, merupakan pernyataan kepada Allah: yakni pernyataan tentang keislaman, keimanan, dan hanya berserah diri kepada Allah SWT dengan penuh harap. Setelah membaca do'a ini, Nabi SAW menyatakan:

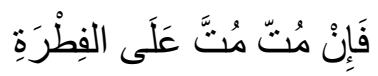

Hadith ini menjelaskan bahwa ketika pernyataan terakhir yang diucapkan seorang manusia, sebagaimana diajarkan Nabi SAW, maka ketika orang tersebut meninggal saat dalam keadaan tertidur, maka ia telah berada atas fitrahnya. Maka dari sini tampak, bahwa fitrah adalah tauhid yang telah diberikan Allah sejak jaman azali, ketika ruh manusia masih berada dalam sulbi Adam, sebagaimana telah difirmankan Allah dalam Q.S. al-A'raf ayat 172 .

Jika diperhatikan secara seksama, terlihat bahwa lanjutan hadith tersebut yang menjelaskan tentang kedua orang tuanyalah yang menjadikan anak tersebut menjadi seorang Yahudi, Nasrani, Majusi, Musyrik, dan sebagainya. Di sini tidak disebutkan menjadi muslim, itu berarti fitrah tersebut adalah Islam, agama tauhid. Begitu pula Q.S. al-Rum ayat 30 yang dengan jelas menyatakan bahwa bahwa fitrah yang dimaksud adalah

37 Abu al-Qasim al-Husain bin Muhammad al-Raghib Al-Asfihani, Almufradat $f i$ Gharib Alqur'an (Mesir: Matba'ah Mustafa al-Bab al-Halabi, n.d.), 382. 


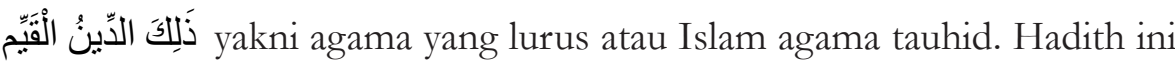
mengingatkan, bahwa anak tersebut dapat menjadi Yahudi, Nasrani, Majusi, karena orang tuanya. Apakah ini berarti fitrah tersebut bisa berubah? Padahal di dalam Q.S. al-Rum Allah menegaskan bahwa fitrah tersebut tidak akan berubah selamanya. Jadi, sekali pun ia menjadi Nasrani, Yahudi, atau Majusi, fitrahnya tidak berubah atau hilang, tapi hanya tertutup oleh didikan dan binaan dari lingkungan, terutama kedua orangtuanya. Hal ini terbukti dengan kisah fir'aun dan lainnya.

Dari sinilah, para ahli pendidikan seperti Arifin, menjelaskan bahwa fitrah merupakan potensi dasar untuk beragama Islam (ad-din alqayyim), Mawabib (bakat) dan Qabiliyyat (tendensi atau kecenderungan) yang mengacu kepada keimanan pada Allah SWT. ${ }^{38}$ Sebagaimana Ramli Awang, yang menyatakan bahwa fitrah manusia adalah cenderung kepada mempercayai Tuhan. ${ }^{39}$ Ramli Awang menjelaskan bahwa fitrah tersebut tertutup cahayanya karena beberapa hal, seperti adanya endapan-endapan syubbah atau debu-debu syaithaniyah. Selain adanya penyimpangan karena mengikuti adat dan warisan nenek moyang, ketaatan membabi buta kepada pimpinan, adanya kesombongan, dan sejenisnya, sehingga cahaya tauhid itu tertutup, bukan hilang. ${ }^{40}$

Hal ini sejalan dengan hadith qudsi bahwa Allah telah menciptakan hambanya cenderung pada agama yang lurus, tapi setanlah menggodanya dengan berbagai hal sehingga fitrahnya tertutup. Agar fitrah ini tidak tertutup, maka diperlukan pembinaan dan pendidikan yang selaras dengan fitrah tersebut. Jika tidak, maka fitrah tersebut dapat rusak oleh tangantangan manusia, sehingga tertutuplah cahayanya. Di sinilah peranan pendidikan Islam, yakni mengembangkan fitrah tersebut sehingga dapat berkembang dan tidak tertutup oleh hal-hal lain.

\footnotetext{
38 Arifin, Ilmu Pendidikan Islam, 97.

39 Ramli Awang, Akidah Penghayatan Taubid Alqur'an (Malaysia: UTM, 2013), 73.

40 Ramli Awang, Akidah Penghayatan Taubid, 82.
} 


\section{Penutup}

Dari pembahasan di atas dapat disimpulkan bahwa hadith tentang fitrah manusia mempunyai banyak jalur sanad yang bernilai maqbul atau dapat dijadikan bujjah. Makna dari fitrah ini adalah potensi tauhid yang sudah diberikan Allah kepada semua manusia sejak jaman azali. Fitrah tersebut tidak akan berubah atau hilang selamanya. Artinya, setiap manusia yang lahir ke dunia ini sudah memiliki potensi untuk beragama tauhid, hanya potensi tersebut perlu dikembangkan melalui pendidikan dan lingkungan yang menunjangnya untuk berkembang. Jika pendidikan yang dilakukan tidak mengembangkan fitrah tersebut, maka potensinya bisa tertutup sehingga seorang dapat mempunyai keyakinan yang berbeda dengan fitrah yang telah diberikan Allah SWT, seperti diisyaratkan dalam hadith Nabi SAW. Di sinilah letak urgensinya pendidikan dan pembinaan yang sesuai dengan fitrah. $\backslash$

\section{Referensi}

Abu al-Qasim 'Ali bin Hasan, Ibn 'Asakir. Tarikh Dimasyq. dar al-Fikr li alThaba'ah wa al-Nasyr, 1995.

Al-Adabi, Shalah al-Din ibn Ahmad. Manhaj Naqd Almutun. Beirut: Dar al-Afaz al-Jadidah, 1983.

Al-Asfihani, Abu al-Qasim al-Husain bin Muhammad al-Raghib. Almufradat fi Gharib Alqur'an. Mesir: Matba'ah Mustafa al-Bab al-Halabi, n.d.

Al-Asqalan, Ibnu Hajar. Tahdhib Altahdhib. Hadrabat: Majlis al-Dairat alNizamiyah, n.d.

Al-Barmaki, Abu al-'Abbas Syams al-Din Ahmad bin Muhammad bin Ibrahim bin Abu Bakr ibn Khalkan. Qiyat Ala'yan. Edited by Ihsan 'Abbas. Beirut: Dar Sadir, 1900.

Al-Damini, Musfar 'Azmillah. Maqayis Naqd Mutun Alsunnah. Riyadh, 1984. Al-Darimi, Abu Muhammad 'Abdullah bin 'Abd al-Rahman. Sunan Aldarimi. Beirut: Dar al-Kutub al-'Ilmiyat, 1971. 
Al-Dzahabi, Syams al-Din Muhammad bin Ahmad. Miæan Ali'tidal fi Naqd Alrijal. Beirut: Dar al-Kutub al-'Ilmiyat, 1971.

Al-Ghazali, Muhammad. Studi Kritis atas Hadith Nabi SAW., antara Pemahaman Tekstual Dan Kontekstual. 6th ed. Bandung: Mizan, 1989.

Al-Khatib, 'Ajaj. 'Usul Alhadith. Damaskus: Dar al-Fikr, 1975.

Al-Maraghi, Ahmad Mustafa. Tafsir Almaraghi. Beirut: Dar al-Fikr, 1974.

Al-Mizzi, Yusuf bin "Abd al-Rahman bin Yusuf Abu al-Hajj)aj Jamaluddin ibn al-Zakiy Abi Muhammad al-Qadha"i al-Kalbiy. Tahdbib Alkamal fi Asma' Alrijal. Beirut: Muassasat al-Risalah, 1992.

Al-Naisaburi, Abu al-Husain Muslim bin al-Hajjaj. Shabih Muslim. Beirut: Dar al-Kutub al-'Tlmiyah, n.d.

Anas, Malik bin. Muwathta'. Edited by Al-A'zhami. Abu Dhabi: Muassasah Zaid bin Sulthan, 2004.

Arifin. Imu Pendidikan Islam. Jakarta: Bumi Aksara, 2002.

As-Sijistani, Abu Dawud Sulaiman bin Al-Asy'ats. Sunan Abu Dawnd. Indonesia: Maktabah Dahlan, n.d.

Awang, Ramli. Akidah Penghayatan Taubid Alqur'an. Malaysia: UTM, 2013.

Azami, M.M. Studies in Hadith Metodology and Literature. Edited by Meth Kieraha. Jakarta: Lentera, 1995.

Aziz, Erwati. 'Tlmu I'llal Alhadith, n.d.

Baidan, Nashruddin. Relasi Gender Dalam Islam. Surakarta: Pusat Studi STAIN Surakarta Press, 2002.

Malik, Imam. Muwathta'. Edited by Al-A'zhami. Abu Dabi: Muassasat Zayid bin Sultan, 2004.

Rahman, Fathur. Ikhtisar Musthalahul Hadith. Bandung: Al-Ma'arif, 1970.

Salih, Subhi. 'Ulum Alhadith wa Mustalahubu. 17th ed. Beirut: Dar al- 'Ilm li al-Malayin, 1988.

Shihab, M.Quraish. Tafsir Almishbah, Pesan, Kesan dan Keserasian Alqur'an. Jakarta: Lentera Hati, 2002.

Turmudzi, Abu 'Isa Muhammad bin 'Isa bin Saurah bin Musa bin adDahhak As-Sulami at-. SunanTurmudæi. Edited by Ahmad Muhammad Syakir. Mesir: Musthafa al-Bab al-Halabi, 1975.

Ya'qub, Ali Mustafa. Kritik. Hadith. Jakarta: Pustaka Firdaus, 1996. 